\title{
Phytoprotection
}

\section{The pine shoot beetle and the Asian Longhorned beetle, two new exotic pests}

\section{J.E. Appleby}

Volume 80, numéro 2, 1999

URI : https://id.erudit.org/iderudit/706184ar

DOI : https://doi.org/10.7202/706184ar

Aller au sommaire du numéro

Éditeur(s)

Société de protection des plantes du Québec (SPPQ)l

ISSN

0031-9511 (imprimé)

1710-1603 (numérique)

Découvrir la revue

Citer cet article

Appleby, J. (1999). The pine shoot beetle and the Asian Longhorned beetle, two new exotic pests. Phytoprotection, 80(2), 97-101.

https://doi.org/10.7202/706184ar d'utilisation que vous pouvez consulter en ligne.

https://apropos.erudit.org/fr/usagers/politique-dutilisation/ 


\title{
The pine shoot beetle and the Asian longhorned beetle, two new exotic pests
}

\author{
James E. Appleby \\ Dept. of Natural Resources and Environmental Sciences University of Illinois
}

PHYTOPROTECTION 80 : 97-101

With the dramatic increase in world trade it is not too surprising that we may be trading more than just the intended goods. Small creatures like insects may tag along in some of the shipments. Even under the strictest inspection procedures there are times when these unwanted creatures remain undetected. Two recent exotic tree insects introduced into North America are the pine shoot beetle, Tomicus piniperda, and the Asian longhorned beetle, Anoplophora glabripennis. These two insects are just recent additions to the more than 4500 exotic organisms now established in the United States (Haack and Cavey 1998).

In 1992 a black beetle, about $4 \mathrm{~mm}$ in length was found infesting a Scotch pine branch in Loraine County, Ohio. It was identified as Tomicus piniperda, the pine shoot beetle by Stephen Wood of Brigham Young University (Haack 1997). The beetle was probably inadvertently imported from Europe in pine wood shipped into the Cleveland, Ohio area. To better acquaint Christmas tree growers with the pine shoot beetle, Appleby and Sadof (1992) produced a 6-min video which briefly explained the life history of the beetle, and showed growers how to identify an infestation. The beetle is native to Europe, Asia, and North Africa where it infests many pine species. The beetle has now been detected in parts of Quebec (http://www.cfiaacia.agr.ca/english/ppc/science/pps/ 1996maps/tppqin.jpg) and Ontario, and many of the Great Lakes states.

Haack (1998), Haack and Lawrence (1995, 1997), Humphreys and Allen (1998), and McCullough and Sadof (1996) give an overview of the distribution, biology, and compliance program for the pine shoot beetle. The beetles overwinter in the adult stage at the base of large pine trees in the protection of the bark crevices. In late winter when the temperature rises above $12^{\circ} \mathrm{C}$ the beetles become active and fly to pine stumps, logs, and slash cut within the past 9 months; pine trees stressed because of drought or other environmental conditions; and pine trees dying of pine wilt disease. At such sites the female beetle chews a hole in the bark, and constructs a tunnel under the bark. Mating probably occurs at this time. The female beetle deposits eggs along the edges of the tunnel. Upon hatching the larvae feed under the bark until late spring when pupation occurs. After about 10 to 14 days as pupae they change into the adult stage. The adult beetles chew holes in the bark and exit. The beetles then fly to the twigs of live Scotch, red, or white pines. The beetle bores a hole in the twig of current year's growth and makes a tunnel of $7-13 \mathrm{~cm}$ in length. A small amount of hardened

Note du rédacteur: le texte ci-dessus est présenté tel que soumis / Editor's note : the above text is presented as submitted. 
resin forms around the edges of the hole. The resin around the hole is a good field sign to use in locating infested twigs. After a few weeks the beetle emerges from the hole and flies to infest another twig. The tunneled area of the twig distal to the exit hole dies. Two to six twigs may be tunneled during the course of the growing season. In late autumn the beetles seek hibernating quarters often at the base of large pine trees where they chew a niche in the bark. There is a single generation per year.

Beetle damage is particularly troublesome to Christmas tree growers because the dead twigs distract from the beauty of the trees, decreasing their sale value. To reduce pine shoot beetle populations, all dead and dying pine trees and stumps should be cut to ground level and the wood burned or converted to chips. All slash should be burned or converted to chips. These procedures ensure that there is no wood available for the development of the larval stages. In instances where stump removal is not practical, stumps should be treated with an insecticide in late winter or when temperatures begin to warm before adult flight to the stumps. Christmas tree growers who have followed such practices have not had a beetle problem.

Because of the potential damage the beetle may cause to the forest industries, the USDA APHIS (Animal and Plant Health Inspection Service) imposed a federal quarantine on areas known to have an infestation. By the end of 1992, there were 42 regulated counties in the USA in six Great Lakes states (Haack and Lawrence 1994). At the end of 1997 there were 224 infested counties in the USA and 18 in Ontario (Haack 1998). In Illinois the beetle has been detected in 24 counties (Appleby and Helm 1998). In 1997 the National Pine Shoot Beetle Compliance Management Program, a voluntary program, was adopted for the Christmas tree and nursery industries (USDA APHIS 1996). McCullough and Sadof (1996) explained in detail a program for Christmas growers. The program involves the use of trap logs that are cut from pine trees in the winter and placed throughout the plantation in late winter to attract female beetles. The trap logs are destroyed in mid spring before the new generation of beetles have a chance to emerge from such logs. All slash and cull trees must be destroyed by mid spring. An insecticide spray is applied to pine trees in the plantation in late spring or early summer just as the new generation of beetles are emerging. Growers must inspect their trees for infested shoots and maintain records of all management practices. To date the compliance program has been very successful.

On August 19, 1996 a Brooklyn resident of New York City notified authorities that he thought vandals had damaged several of the Norway maple trees in his area. On August 20, 1996, Harry Rothar of the Parks and Recreation Department determined that a large beetle was the cause. He mailed a specimen to $E$. Richard Hoebeke of Cornell University who identified the specimen as Anoplophora glabripennis, the Asian longhorned beetle (Haack et al. 1996). This was the first instance in North America of an established population of this beetle.

Haack et al. (1996) reviewed the Chinese literature and presented information on the native range, host range, previous interceptions, life history, description of life stages, attack behavior, and damage. The beetle is native to China, Korea, and Japan. The climatic range of the beetle in China is comparable to that which occurs from Milwaukee, Wisconsin to Cancun, Mexico. In Asia, the host trees include species of maple, poplar, willow, chinaberry, mulberry, plum, pear, black locust and elm. In New York species of maple, poplar, willow, and horsechestnut are attacked. Throughout its native range the beetle usually has one generation a year but occasionally some individuals require 2 years (Peng and Liu 1992). In New York some residents recall seeing adult beetles in mid-May and entomologists there observed adults from August through October. Adult beetles may fly some $1000 \mathrm{~m}$ in search of new 
host material. Adult beetles feed on the tender bark of twigs and small branches. The female beetle chews a small funnel shaped depression in the bark of a limb, trunk, or exposed root. It then reverses position and inserts the tip of its abdomen into the depression and inserts a single egg under the bark. The female probably deposits about 30 eggs in other such sites during its life span of probably 2 months or more. Upon hatching the larva feeds in the cambial region but as it changes into the third and fifth instars it feeds in the xylem. The mature larva is about $50 \mathrm{~mm}$ in length. The beetle typically overwinters in the larval stage. Pupation lasts about 2 to 3 weeks and occurs within the larval gallery. When the adult beetle emerges it chews a circular exit hole 6 to $12 \mathrm{~mm}$ in diameter. The adult beetle is 20 to $35 \mathrm{~mm}$ long. The beetle is shiny black with about 20 small irregular white areas on each elytron. The antennal segments are banded black and white.

The beetle attacks recently cut logs, stressed and apparently healthy trees (Gao et al. 1993; He and Huang 1993; Peng and Liu 1992). For several years different generations of adults will tend to reinfest the same portion of a tree until that area dies. In New York the trunk diameter of the trees attacked ranged from 10 to $60 \mathrm{~cm}$. Larval tunneling in the branches weakens the structure of the wood, and often during wind storms affected branches break creating hazardous conditions at the base of the tree. Branches as well as tree mortality can occur. The beetle poses as a serious threat to the maple syrup industry of North America as maple species are a prime host. Also threatened is tourism and property values.

In July 1998 the beetle and infested trees were discovered in the Ravenswood area of Chicago (Appleby 1998; Poland et al. 1998). On July 10, 1998 a Chicago Parks District employee discovered some large beetles emerging from firewood which he obtained from the Ravenswood area. Authorities were notified and immediate investigations began in the area. Evidence strongly indicates that the beetle arrived from China in wooden pallets shipped to a local importer. Some Norway maple trees were heavily infested suggesting that the beetle probably became established some 5 or more years prior to the detection. Local Chicago TV, radio, and newspapers gave excellent coverage of the infestation. As a result of the publicity local citizens found other much smaller infestations in Summit, a suburb about 15 miles southwest of downtown Chicago, and another infestation near Addison which is about 5 miles southeast of O'Hare International Airport. The USDA APHIS PPQ, Illinois Department of Agriculture, Chicago Bureau of Forestry, Chicago Park District, Chicago Streets and Sanitation, and the USDA Forest Service cooperated in devising an eradication program. Quarantines were established in all infested areas. Intense tree inspections found infestations in Norway and silver maples, boxelder, elm, horsechestnut, apple, and green ash. During February and March 1999 all trees found to be infested were cut to ground level, converted to chips and burned. Roots were removed to a depth of $30 \mathrm{~cm}$ within $1 \mathrm{~m}$ of the radius of each tree.

In December 1998 the USDA required that all solid wood packaging materials from China be treated for pests before arrival in the United States. It appears that the Chinese government is complying with the agreement.

Since September 1999 slightly more than 1000 infested trees have been destroyed in Illinois with the eradication efforts costing about $\$ 1.5$ million. During the 1999 spring season in areas where trees were removed, new trees were replanted which included various oaks, Kentucky coffeetree, Turkish filbert, linden, ginkgo, catalpa, yellow poplar, and honey locust.

No beetles were found during 1999 in the Ravenswood area. An important lesson learned from the Chicago infestations is that it is extremely important to have the news media involved, as in many instances private citizens learning information from the news media alerted officials to an infestation. The establishment of a hotline number for 
the public to use to alert officials of new beetle sightings proved valuable. Tree climbers and workers in tower trucks in Chicago discovered more than 200 infested trees during 1999 that were overlooked by ground surveyors. Inspections high in the tree canopies are essential if eradication is the goal. In Chicago good cooperation between city, state, and government agencies made the beetle eradication program so far successful.

As world travel and trade continues to increase, it is imperative that government agencies and the public be vigilant and report any unusual insects or plants to authorities.

The following Internet sites provide additional information about these insects as well as other exotic insects:

http://www.aces.uiuc.edu/ longhorned_beetle/;

http://www.aphis.usda.gov/oa/alb/ alb.html;

http://willow.ncfes.umn.edu/;

http://www.aphis.usda.gov/ppq/ longhorn.html;

http://www.agr.state.il.us/ asianbeetleinfo.html;

http://www.ceris.purdue.edu/napis/ pests/alb/;

http://www.pfc.cfs.nrcan.gc.ca/ biodiversity/exotics/;

http://canexplore.gc.ca/;

http://www.cfia-acia.agr.ca/english/ ppc/science/pps/1996maps/ tppqin.jpg.

\section{REFERENCES}

Appleby, J.E. 1998. Asian longhorned beetle invades Chicago. Dept. Natural Resources Environmental Sciences, Univ. of Illinois, Leaflet No. 100In. 2 pp.

Appleby, J.E., and C. Helm. 1998. Illinois insect invaders. The Illinois Steward 8(3) : 16-17.

Appleby, J.E., and C.S. Sadof. 1992. The pine shoot beetle. Video No. 035. Univ. of Illinois College of ACES, Marketing and Distribution Services.

Gao, R., X. Qin, D. Chen, and W. Chen. 1993. A study on the damage to poplar caused by Anoplophora glabripennis. For. Res. 6 : 189-193.
Haack, R.A. 1997. Early history and spread of Tomicus piniperda in North America. Pages 146-153 in 1997 Japanese beetle and the pine shoot beetle regulatory review : Proceedings, Louisville, KY, 24-26 February 1997. USDA APHIS, Riverdale, MD.

Haack, R.A. 1998. An exotic bark beetle and wood borer update: Old friends and new finds. Newsletter Michigan Entomol. Soc. 43(1) : 11-12.

Haack, R.A., and J.F. Cavey. 1998. Insects intercepted on wood articles at United States ports-of-entry and two recent interceptions: Anoplophora glabripennis and Tomicus piniperda. Pages 172-187 in C. Perez and C. L. Gotor (eds.), Proceedings : International forest insect workshop, August 18-21, 1997. Pucon, Chile. Corporacion Nacional Forestal, Santiago, Chile.

Haack, R.A., and R.K. Lawrence. 1994. Geographic distribution of Tomicus piniperda in North America : 1992-1994. Newsletter Michigan Entomol. Soc. 39(4) : 14-15.

Haack, R.A., and R.K. Lawrence. 1995. Attack densities of Tomicus piniperda and Ips pini (Coleoptera : Scolytidae) on Scotch pine logs in Michigan in relation to felling date. J. Entomol. Sci. 30(1) : 18-28.

Haack, R.A., and R.K. Lawrence. 1997. Highlights of Forest Service research on Tomicus piniperda : 1992-1996. Pages 115-122 in 1997 Japanese beetle and the pine shoot beetle regulatory review: Proceedings, Louisville, KY, 24-26 February 1997. USDA APHIS, Riverdale, MD.

Haack, R.A., J.F. Cavey, E. R. Hoebeke, and K. Law. 1996. Anoplophora glabripennis : a new tree infesting exotic cerambycid invades New York. Newsletter Michigan Entomol. Soc. 41(2-3): 1-3.

He, P., and J.F. Huang. 1993. Adult behavior of Anoplophora glabripennis. Acta Entomol. Sinica $36: 51-55$.

Humphreys, N., and E. Allen. 1998. The pine shoot beetle. Canadian For. Serv., Pacific Forestry Centre, Exotic Forest Pest Advisory No. 2, Victoria, BC. 4 pp.

McCullough, D.G., and C.S. Sadof. 1996. Pine shoot beetle compliance program for Christmas trees : A manual for Christmas tree growers. Michigan State Univ. Ext. Bull. E-2615. 15 pp.

Peng, J., and Y. Liu. 1992. Iconography of forest insects in Hunan, China. Hunan Forestry Dept., Institute of Zoology, Academia Sinica. 
Poland, T.M., R.A. Haack, and T.R. Petrice. 1998. Chicago joins New York in battle with the Asian longhorned beetle. Newsletter Michigan Entomol. Soc. 43(4) : 1517.
USDA APHIS. 1996. Pine shoot beetle compliance management program. USDA APHIS, Plant Protection and Quarantine, Domestic and Emergency Programs. Riverdale, MD. 24 pp. 